History from the grave? Politics of time in Spanish mass grave exhumations Berber Bevernage and Lore Colaert

Memory Studies 2014 7: 440 originally published online 8 July 2014

DOI: $10.1177 / 1750698014537669$

The online version of this article can be found at:

http://mss.sagepub.com/content/7/4/440

\author{
Published by: \\ (SAGE \\ http://www.sagepublications.com
}

Additional services and information for Memory Studies can be found at:

Email Alerts: http://mss.sagepub.com/cgi/alerts

Subscriptions: http://mss.sagepub.com/subscriptions

Reprints: http://www.sagepub.com/journalsReprints.nav

Permissions: http://www.sagepub.com/journalsPermissions.nav

Citations: http://mss.sagepub.com/content/7/4/440.refs.html

>> Version of Record - Sep 3, 2014

OnlineFirst Version of Record - Jul 8, 2014

What is This? 


\title{
History from the grave? Politics of time in Spanish mass grave exhumations
}

\section{Berber Bevernage}

Ghent University, Belgium

\section{Lore Colaert}

Ghent University, Belgium

\begin{abstract}
During the last decade, a Spanish memory movement has exhumed a great number of mass graves from the Civil War (1936-1939) and Francoist repression (1939-1975). This exhumation campaign is often interpreted in psychopathological terms as a natural reaction to a traumatic past, and as proving that this past should be healed by a therapeutic memory that fosters closure - a vision that we call "trauma-therapy-closure (TTC) time." Although this vision is in line with an internationally widespread "transitional justice" discourse, it should be critically analyzed. We argue that the Spanish situation does not prove the naturalness and universal applicability of trauma-therapy-closure time. Although we do identify aspects of this trauma-therapy-closure vision in an influential exhumation group, this vision is contested by local actors and sections within the memory movement that engage in alternative politics of time. Therefore, we demonstrate how the case of Spain reveals how traumatherapy-closure time, rather than being natural or universal, is actively disseminated on a local level.
\end{abstract}

\section{Keywords}

closure, exhumations, historicity, memory boom, politics of time, representation, Spain, transitional justice, trauma

\section{Introduction}

For many years, the Spanish transition to democracy (1975-1978), based on amnesty and a socalled "pact of silence," served as a model for other transitions worldwide (Aguilar, 2002; Alonso and Muro, 2010: 1-2; Davis, 2005: 863-866). Spain's successful shift from the Francoist dictatorship to democracy was often conceived as proving the viability of amnesty and amnesia in overcoming violent pasts. However, due to recent evolutions, the Spanish case is increasingly seen as evidence of the disfunctionality of politics of forgetting (Davis, 2005: 880). Analysts now refer to Spain to promote an active confrontation of the past as the appropriate procedure to put it to rest.

This idea of a need for active confrontation of the past has, roughly since the 1980s, become a core premise of the so-called field of "transitional justice." Scholars such as Teitel (2003: 86) and 
Bevernage (2012: 13-14) have argued that this transitional justice premise depends on, and reacts to, a particular "non-linear" concept of time in which the past, so to speak, gets stuck in the present. We elaborate on this thesis by describing this notion of temporality, (consciously or unconsciously) adopted by transitional justice practitioners and theorists, as trauma-therapy-closure time (henceforth TTC time). It has become common sense among transitional justice practitioners to describe violent pasts in psychopathological terms as "traumatic" and therefore in need of therapy and, eventually, closure. We speak about this threefold sequence in terms of "time" because of two reasons. First to demonstrate how it is commonly conceived as a sequence that has to be worked through step by step and chronologically. Second in order to highlight its ambiguous relation to nonlinear temporal experiences - recognizing their existence but pathologizing them. In the TTC time framework, the traumatic past does not go away with the passing of time, but inevitably remains present if not actively addressed. Since this continuing presence of the past is considered pathological, therapy is needed. Remembrance and revelation of "truth" are considered the proper way to cleanse and eventually close the past's "festering wounds." As Desmond Tutu (1998) expresses the idea (p. 22), only after having "looked the beast of the past in the eye," the door on the past can be shut. With this closure, linear time is set straight again.

In Spain, the thesis of TTC time, and especially the idea that therapy needs to be provided to obtain closure and prevent the past from returning, seems at first sight to be confirmed by the recent rise of a movement that strives for the "recovery of historic memory." This movement argues that the transition of 1975-1978 failed to come to terms with the legacy of the Civil War (1936-1939) and dictatorship (1939-1975) because it did not properly remember or acknowledge the crimes of Francoism against republican families (Fernández de Mata, 2004: 2528-2529; Silva and Macías, 2003: 119-126; Villarroya i Font et al., 2006: 9-10). Numerous organizations therefore lobby for public acknowledgement of the Francoist repression and reparations for its victims. Furthermore, they demand the revision of history textbooks, annulment of politically motivated court sentences, disclosure of archives, removal of Francoist public symbols, legal proceedings against Francoism, and exhumation of mass graves.

The recent turn in Spain's memory politics has been called the "mass grave phenomenon" (Fernández de Mata, 2004: 2527) and is indeed spearheaded by exhumation organizations. The memory movement organizes many activities such as protests and tributes, but in the context of this article, it is important to note that it is the practice of mass grave exhumations that has come to function - both in public opinion and academic analysis - as a symbol of TTC time. We also recognize some aspects of TTC time in the discourse of the most influential exhumation group, the Asociación para la Recuperación de la Memoria Histórica (ARMH). ${ }^{1}$

ARMH members and sympathizing intellectuals ${ }^{2}$ often present mass graves in pathological terms as sites of traumatic memory. Espinosa Maestre (2007), a historian involved in different initiatives of the memory movement, interprets the presence of unexcavated mass graves as symbolizing a past that was not properly dealt with and got "stuck" in the present. According to ARMH, Spain's captured memory can only be freed by a second "memorial" transition that now really breaks with the Francoist past, and recovers and speaks out the truth (Silva, 2008). Since "one cannot escape from the past," such an "awakening" (Silva, 2008: 14) of memory, according to ARMH, is also "logical", "normal"and"natural" (ARMH volunteer, 2011, interview during Chillón exhumation; Psychologist working with ARMH, 2010, roundtable, Universidad Carlos III; Emilio Silva, cited in Bolaños, 2010). ${ }^{3}$

"Normalizing" the past by breaking the "taboo" is, according to ARMH president Emilio Silva, the "biggest victory" of the Spanish exhumation campaign (Silva, 2010). "The first exhumation broke with silence," and since then "the truth occulted by Francoism started to come to light" (Silva, 2008: 14). Although this process of breaking silence can be painful, ARMH believes the 
exhumations eventually serve as collective "therapies" (ARMH, 2012a). Fernández de Mata (2010), an anthropologist who has worked in several exhumations, also defends this idea: "Part of the pain contained in the memory generated by trauma is somehow exorcised when, like a skeleton in a grave, it is unearthed [...] A true logotherapy takes place" (p. 295).

This therapy of truth revealing ultimately serves closure. The link between revelation and closure is clearly expressed in the title of a 2008 Amnesty International manifesto about Spain, often quoted by memory campaigners and attributed to Louis Joinet, a United Nations Special Rapporteur: "you need to read the page before turning it." While the political right in Spain argues that the past "ya pasó" ("is already passed") and that the memory movement "reopens old wounds" (e.g. Agencias, 2008; Silva, 2011: 14), the ARMH, to the contrary, claims that the past has not passed yet, and that its campaign is needed precisely because it closes "a door"or "a pain." Although the ARMH does not foresee a concrete end to its exhumation campaign, the idea of a pending and necessary closure is inherent in its campaign in which each single exhumation is followed by a reburial.

Because TTC time is presented as natural and logical, the ARMH tends to ignore its own active role in constructing and disseminating this notion, and thereby also its engagement in a "politics of time"- "a politics which takes the temporal structures of social practices as the specific objects of its transformative (or preservative) intent" (Osborne, 1995: xii). Because academics working on the Spanish exhumation movement seldom question the allegedly natural character of the temporal sequence of trauma, therapy, and closure, they only discuss the party political dimensions of exhumations and ignore these more implicit political dimensions.

We therefore want to question the allegedly natural and teleological character of transitional justice discourse and TTC time. Although we recognize the psychological trauma that can be experienced by victims of Francoism and the affective closure that can be obtained after exhumation and reburial, we will conduct a critical analysis of transitional justice discourse and its idea that the recognition of collective trauma, provision of therapy, and striving for closure is the only possible or legitimate way of dealing with violent pasts. In order to do so, we will first demonstrate that the transitional justice vision on time, far from being experienced as natural or logical, is sometimes contested, not only by persons supporting public forgetting, but also by groups supporting remembrance.

Although contestations of TTC time can be found throughout the Spanish memory movement, in this article two specific cases will be discussed. In the first case, some relatives of victims of Francoism oppose an ARMH exhumation. Second, we describe how a different organization, called "Federación Estatal de Foros por la Memoria" (henceforth "Foro"), also exhumes mass graves but does not share the ARMH's therapeutic approach. ${ }^{5}$ In the second part of the article, we try to understand why, if the TTC interpretation of the exhumations is contested, it has gained predominance. To answer this question, we analyze how the ARMH constructs its particular concept of time.

By focusing on the case of Spain, we want to demonstrate how the relatively new phenomenon of transitional justice and its notion of TTC time are disseminated on a local level. We believe that the hegemony of transitional justice discourse and its ideas on time and on "proper" ways of remembrance is so strong that it has become a common sense that can hardly be questioned. Far from criticizing the exhumation movement or favoring one organization over another, our aim is to show, that the use of some of these temporal notions by local organizations can have important, although sometimes unintended, political implications. Although we understand that it can be important for organizations such as ARMH, which face continuous opposition, to align with internationally dominant transitional justice discourse, we believe that this alignance could form a threat for these very organizations in the longer run. 
By studying the connection between time or historicity and dealing with the dead, we, finally, want to contribute to the discussion in philosophy of history on the link between history and death - a discussion that until now has not differentiated enough between different ways of experiencing history and, more specifically, historical time and lacks sound empirical foundation. We want to empirically test Ewa Domanska's (2005) interesting thesis that "history begins in the grave" (p. 398). For Domanska, the discourse of death is a historical discourse:

Indeed when speaking of the dead body, we touch the very essence of historical discourse which, arguably, originates from the contemplation of dead body. Without death there would be no history. History feeds on death.

We argue that historicity and death are indeed related but that this relation is not unequivocal. On the contrary, subtle differences in exhumation practices and discourses can lead to radically different visions on time, history, and memory.

\section{Spanish mass grave exhumations: an overview}

The first scientific exhumation of a mass grave was initiated by Emilio Silva (2000) in order to find the body of his grandfather, killed in 1936. This event is generally regarded as the exhumation movement's founding moment. Since then, several associations have exhumed over 6000 bodies in about 300 graves and they claim to search for no less than 130,000 missing persons, mainly republican civilians murdered by Francoist forces in extrajudicial killings during and after the Civil War. This grassroots movement gradually gained attention from national and international media, and received support from the United Nations (UN), Amnesty International, transitional justice organizations, and academics worldwide. In 2007, Spanish Parliament adopted the "Law of Historic Memory" that stipulates that the state should facilitate the exhumations. In practice, however, state support has been very limited and in September 2012 was even canceled completely by the governing conservative Popular Party. In general, the movement faces opposition by large parts of public opinion that consider the exhumations ideologically motivated and violating the transition's reconciliatory spirit.

If we take a closer look at the exhumation movement, we see a mosaic of diverse national and local organizations. ${ }^{6}$ The current exhumation campaign ${ }^{7}$ was initiated when Emilio Silva and Santiago Macías founded the previously mentioned independent "Asociación para la Recuperación de la Memoria Histórica" (ARMH). Soon, however, new associations sprung up all over Spain. Some of them became local sections of the ARMH, some were just loosely related, and others clustered around a second organization, the "Federación Estatal de Foros por la Memoria" (henceforth Foro) that is linked to the communist party. Besides ARMH and Foro, academic teams (e.g. the Basque Aranzandi) and numerous local and regional organizations also perform exhumations. The ARMH has been most successful in gaining recognition and - together with Aranzadi-exhumes most mass graves, followed by Foro. Although each organization has different aims, they all advocate the right of survivors to know what happened and the restoration of the republican victims' dignity.

\section{Trauma time contested}

As mentioned above, exhumations are sometimes contested. Francisco Ferrándiz summarized some of the polemics surrounding the Spanish exhumations. He shows how some memory organizations for several reasons prefer to preserve mass graves as evidence and consider horrific images of bones a sign of disrespect toward the dead (Ferrándiz, 2007; Fernández de Mata, 2010). Our study, however, does not consider opposition to exhumations in general but focuses on opponents 
of the notion of time that comes with ARMH exhumations. ${ }^{8}$ In one of our fieldwork studies, Chillón in Castilla la Mancha, we came across this kind of contestation. ${ }^{9}$

In 2009, two historians of Chillón published a book on nine local men killed by Francoists in 1939 (Mansilla Escudero and Montes Oviedo, 2009). During the book presentation, the historians suggested exhuming these victims. Yet one family, the Garcías, ${ }^{10}$ contested the exhumation. One of the granddaughters of the murdered Juan García read aloud an open letter describing how her family commemorates her grandfather every 1 st of November at the mass grave site and how the families erected a monument there in 1988, which is regularly visited and also hosts a yearly commemoration by the local socialist party. The granddaughter explained how her father believed the bodies had to stay where they were as a "testimony" to future generations (Carmen García, 2009 , open letter, Almadén). In an interview, her father indeed stated that reburying the victims in the cemetery "to him would equal forgetting" (Pedro García, 2011, interview, Almadén). During the book presentation, however, some families were in favor of exhuming. The Garcías therefore, gave in and allowed an exhumation request to be sent to the ARMH.

In October 2011, the ARMH arrived in Chillón and held a town meeting before starting to dig. At this meeting, the García granddaughters again took the floor. They questioned the exhumation's healing aspect, explaining that the process looked very painful to them and that they preferred not to know more than was already known about the murdered. Moreover they considered the monument and commemorations a proper way to remember: "This is not a mass grave. I consider this sufficiently remembered." One of the granddaughters turned to the audience:

Do you really think we will give them another character or more dignity than they already have by moving them to another place? [...] According to me, if we divide them over the cemetery, they will be just some other dead, while to us they are not just like other dead [...]. That is why they are better of where they are.

That same afternoon, the ARMH started excavating while the García granddaughters observed them suspiciously. The Chillón case not only shows that not everyone considers exhumations the "proper," let alone the only possible, way to remember the dead. It also contradicts some of the assumptions of TTC time that characterize part of the discourses of transitional justice and ARMH. First, it counters the dominant idea that the existence of unexcavated mass graves necessarily implies that the past is traumatic and has not been properly dealt with. Far earlier than 2000, victims' relatives in Chillón constructed a "lieu de mémoire" at the mass grave site and organized commemoration practices there. The murder was well known to the villagers because of oral testimonies and since 2009 because of the book. Although public commemoration of the Civil War was generally repressed or strongly discouraged by local and national political elites even after the transition, Chillón's situation is not unique. In many villages, people already during the period of the "pact of silence" paid tribute to their victims with flowers or mourning rituals often performed at the mass graves. ${ }^{11}$ Even if these practices were usually private and of limited scope, they undermine the widespread idea that prior to the ARMH's foundation in 2000, there was only silence and trauma.

The discussed case also modifies the dominant idea that the exhumations finally reveal the truth hidden by Francoism and the "pact of silence." In Chillón, the exhumation did not provide much new knowledge about the location of the grave or about the number and identity of the victims. The exhumation mainly confirmed and acknowledged information that was already found in archives and oral testimony.

Another, related aspect of TTC time in ARMH discourse is the idea that a second "memorial" transition is needed. Again, Chillón illustrates that this idea is not present in all villages prior to contact with the excavation team, and this way the case undermines the seemingly teleological character of the need for the completion of the transition. 
Finally, the case disproves that therapy and closure are the only alternatives to the "ya pasó" attitude. The letter of the Garcías shows how, prior to the exhumation, not all victims' relatives agree about being in need of therapy and closure. On the contrary, they consider the memory of their grandparents and parents something to be proud of and a useful reminder for future generations to fight injustice.

The Garcías and some other families with mixed feelings did not impede the exhumation process out of respect for families who were in favor (Pablo García, 2011, interview, Almadén). During the town meeting, the other families promised the Garcías that the victims would be reburied collectively (Town meeting, 2011, Chillón). Once the exhumation started, some of the Garcías actually became closely involved, and by the end of the exhumation, they seemed to have revised their opinion (García granddaughters, Chillón).

If in Chillón, the Garcías opposed the exhumation, some groups do not contest the exhumations themselves, but particular discourses and practices around them. In Candeleda (Castilla la Mancha) in May 2010, for instance, the ARMH got involved in a conflict with a local Foro. A Foro exhumation there was canceled because local protagonists (the landlord, the mayor, and even some archaeologists hired by Foro) did not agree with Foro's political rhetoric. The ARMH took over and claimed that Foro wanted to make "political promotion" "at the cost of the victims' relatives" (cf. Pérez et al., 2010; Mestre, 2010). The Foro in its turn accused ARMH of "privatization of memory." According to Foro member Javier Mestre (2010), the dead belong to the struggle for the Republic and to collective memory and therefore cannot be claimed even by relatives. According to Foro president José María Pedreño, leaving the fate of the dead in the hands of relatives and private associations such as ARMH equates to "burying memory" (Ferrándiz, 2007).

This is just one example of the many conflicts between ARMH and Foro, and the tensions partly relate to differing visions on time. ${ }^{12}$ Much like ARMH, Foro rejects the "ya pasó"-argument which is often used to legitimize the amnesty arrangement and pact of silence. As a psychologist related to the Foro argues, the fact that something occurred a long time ago does not absolve it from being a crime (Álvarez Meríno, 2010). "Neither is it valid," Javier Mestre (2010) argues, "to say that the dead are already dead, that it happened long ago, that bygones are bygones."

The Foro, however, does not share ARMH's use of TTC time. It puts less stress on the idea of collective trauma. If ARMH stresses the therapeutic value of exhumations, Foro primarily ascribes political rather than therapeutic value to exhumations. ${ }^{13}$ Moreover, Foro does not strive for closure or for a second "memorial" transition as ARMH does. Rather, its political discourse is organized around a temporal notion of regeneration or renaissance that aims at nothing less than the return of the Republic (Foro por la Memoria de Córdoba, 2004). ${ }^{14}$ For Foro, the history encountered in the mass graves provides clear lessons for present and future life: it is conceived as a true teacher of life-historia magistra vitae. Dead republicans for Foro are sources of moral and political reference, rather than serving as objects of - in Foro's words - "nostalgic commemoration." Therefore, Pedreño assures that "Foro is not past, Foro is no nostalgia, Foro is present for the future" (LaManchaRojaTV, 2010). The contrast between ARMH's TTC time and Foro's "regenerational" time is most evident when Foro describes itself as "new popular front.",

\section{Disseminating TTC time}

Above we have questioned the naturalness, universality, and teleological necessity of ARMH's notions of TTC time that posit the coming of a second "memorial" transition in Spain as a quasiinevitable, therapeutical, and concluding complement to the transition of 1978. Yet, we also wrote that ARMH eventually has often been successful in dealing with criticism. In Chillón, the Garcías 
eventually became supportive of ARMH's exhumation. In Candeleda, the dispute between ARMH and Foro was decided to the former's advantage. This is in line with the organization's relative success in gaining support and overcoming opposition in Spain. Therefore, it should be asked how ARMH could be so successful in disseminating its visions - especially on time. We explain this success by pointing first to the popular use of exhumations as master metaphors for proper remembrance, second to the representation and appropriation of the dead in a way that reinforces the alleged naturalness of TTC time, and third to a "mass grave pedagogy" promoting norms about how to deal with the past. ${ }^{15}$

\section{Exhumations and reburials as master metaphors for trauma, therapy, and closure}

The success of TTC time is partly due to the use - not only by ARMH campaigners but also by academics, journalists and artists - of exhumations and reburials as master metaphors for traumatic memory, therapy, and closure.

In order to claim that the past was not sufficiently dealt with during the transition and that Spain before 2000 suffered a collective trauma, memory campaigners often use mass graves as metaphors for traumatic memory. ${ }^{16}$ Unexcavated graves are described in pathological terms as "open wounds" that "scar" the Spanish landscape (Servimedia, 2012; Silva and Macías, 2003: 119). The material permanence of mass graves serves well as a metaphor for the continuing presence of traumatic memory. Mass graves become a symbol for a past that is buried, but lurking under the surface, "sleeping" and "waiting" to be awoken ("despertado") (cf. Silva, 2000, 2008, 2011: 11; Silva and Macías, 2003: 21). Their physical proximity, centimeters under the surface, is used to metaphorically stress how memory inevitably and almost automatically re-appears. To quote Silva, "Spain is very fragile. One scratches a little in its past and it starts to break" (Facebook, August 2010). ${ }^{17}$

In order to illustrate that a second "memorial" transition can be realized through exhumations, ARMH presents mass graves as containers of suppressed memory, places "where memory dwells," or "pits of silence/memory" (Las fosas del silencio, 2003; Macías, 2003: 127). If mass graves serve as metaphors for suppressed memory, their exhumation stands for truth revealing and remembrance. Exhumations are often interpreted as revealing "the occulted truth" and "unearthing memory" (Silva, 2007, 2008). The dead and the earth themselves often seem to tell this truth, as in Silva's (2008) quote, "the republicans that had lingered all those years in the mass graves [...] [started to] tell their histories, who they were, which ideas they held, how they got murdered, and how their families endured the repression of the dictatorship"; or in a Facebook post from an ARMH supporter, "the earth is talking and you know how to listen to it." As mentioned, the truth and remembrance aspects of the exhumations are considered therapeutic. And as a logical complement to notions of trauma and therapy, ARMH reburials tend to be associated with mourning and closure. Once the exhumation and reburial process is complete, ARMH claims to have helped "healing" or "closing" "open wounds" (cf. Silva and Macías, 2003: 119; ARMH, 2012b; Psychologist Guillermo Fouce working with ARMH, 2010, roundtable Universidad Carlos III; Santiago Macías, 2010, roundtable 10 years ARMH Ponferrada). ${ }^{18}$

This popular use of mass graves, exhumations, and reburials as psychopathological metaphors has important consequences. The interpretation of mass graves as "open wounds" or as traumatic memory reinforces the perceived need to "repair" or "close" these wounds with a new transition. The reference to the presence of mass graves as metaphors for the inevitable and quasi-automatic reappearance of memory conceals the active role of "memory agents" and naturalizes TTC time. It restrains us in fully understanding that the course of events could have taken different directions in 
Spain. "Politics of forgetting" could have remained successful in representing the past as "passed" or other ways of dealing with the past-involving remembrance without therapy, closure, or even exhumations - could have gained predominance.

Besides, metaphors of "unearthing" and "revelation" sometimes overemphasize the truth revealing aspects of exhumations, while in fact, exhumations in Spain often confirm pre-existing local knowledge, ${ }^{19}$ or are in line with historical research carried out from before 2000 up until now (Boyd, 2008; Ruiz, 2009).

We are convinced that exhumations are important in terms of acknowledgement, as ARMH rightly stresses. We also believe they can stimulate critical collective memory. Yet this is not automatically the case. Foro spokesmen, therefore, rightly warn that "recovering human remains does not necessarily mean recovering memory; one can exhume victims' remains and at the same time effect forgetting" (Foro, 2010); and intellectuals supporting the ARMH as well caution that "the digging" is not the end, but the beginning, and that it should be accompanied with a "correction" of history (Viçenc Navarro, 2010, roundtable 10 years ARMH, Ponferrada). We do not accuse the ARMH of actually effecting forgetting as the Foro clearly implies. Yet, the link between exhumations and collective memory indeed depends on the discourses and practices that accompany it. Ultimately, the equation of exhumations with truth and remembrance - and the absence of exhumations with ignorance and forgetting-leaves little space for other memory practices such as the ones in Chillón, and reinforces the problematic idea that before the first scientific exhumation in 2000 there was only silence and trauma.

\section{Appropriation of the dead through affective familial bonds}

One outspoken difference between ARMH and Foro is the way they represent the dead (what we call "privileged representations" of the dead) and the way they appropriate the dead or make claims about who can speak for them (what we call "privileged representatives" of the dead). The issue of privileged representation and representatives is a prominent feature of the tensions between the two organizations and partly relates to different visions on time.

According to Foro, ARMH depoliticizes the dead by representing them as lost family members (e.g. grandfathers or fathers), whose best representatives are their surviving relatives, rather than as fallen republicans, who can best be represented by the political heirs of their struggle. When speaking about the dead, Foro uses political titles, such as compañeros or camaradas, instead of terms referring to blood ties. For Foro, ideological ties are at least as important as, or even more important than, blood ties. Addressing the dead after an exhumation in Menasalbas, for example, Jose Maria Pedreño (2011) spoke the following words:

Dearest comrades: and I call you comrades, because [...] I do not share the same blood with you, but, nevertheless, my mind is inhabited by the same ideas of Justice and Liberty that inhabited yours. It is not the same as saying son, grandson, brother or nephew [...] Although it is almost the same as relative because for us, and for you, saying comrade is sharing ideas and struggle for a better world [...]

At the grave of the "five of Celorio" (Asturias), two Foro archaeologists uttered similar words, saying that "we are no grandchildren or children [...] but we are something important [...] compañeros," and claiming that in order to exhume a grave "consent of the relatives is important but not necessary" (Foro por la Memoria, 2006). Foro recognizes the suffering of relatives, but considers this mere fact insufficient to entitle them to represent the dead.

Typically, Foro resists discourses that put too much stress on victimization by, for example, stressing the innocence of victims. The republican dead, it is argued, 
were not assassinated, imprisoned or exiled due to personal rancor, coincidences or envies, as they have always tried to make us believe. It is sure they were not innocent: they were absolutely guilty of having desired and struggled for a better world. (Foro, 2011)

It is assured that the republican dead were not killed "for being victims" but "for being combatants" and that they should consequently be remembered as such (García Bilbao, 2010).

Although the ARMH seldom publicly reacts to Foro criticism, their overall position is that nobody can claim the monopoly over representing victims (Ferrándiz, 2007: ff. 30). Yet, although the organization does this less explicitly and unequivocally than Foro, ARMH also engages in a particular representation of victims. Their representation, as Layla Renshaw (2011) demonstrates, tends to individualize or privatize them (to the level of the family rather than the broader collective) and, to a certain extent, also depoliticize them. ${ }^{20}$ Especially when it comes to privileged representatives, it is clear that ARMH favors blood ties over ideological ties. Generally, ARMH tends to privilege representations that depict the dead as fathers or grandfathers rather than combatants and they pay a lot of attention to testimonies of surviving relatives (often widows) who tend to become the main symbol of victimization, even more so than the dead themselves.

There are several plausible explanations for ARMH's focus on blood ties. Besides a genuine respect of ARMH volunteers for the affective bonds between villagers and their perished relatives, one explanation is that the focus on family values and on the universal right of relatives to bury their dead offers a position that is less open for contestation than Foro's explicitly political representation of the dead. The continuing power of conservative political factions makes addressing the past far from self-evident in Spain and in this context referring to widely shared values is less provocative. $^{21}$

However, the focus on blood ties also reinforces ARMH's visions of time. Clearly there is a close link between the focus on surviving relatives and the focus on trauma and therapy. Yet, the most important link between ARMH's stress on blood ties and their conceptualization of time is provided by the mediating concept of "generations." Generational thought figures prominently in the discourse of ARMH and its observers in media and academia. Printed T-shirts declare they are "grandchildren of peace," the debt of Spanish society is defined as one of a generation of grandchildren (e.g. Villarroya i Font et al., 2006: 7) and a famous slogan goes "why have the fathers of the transition left my grandfather in the ditch?" (cf. ARMH, 2012c).

Together with the focus on blood ties, the reference to generations naturalizes the threefold temporality that characterizes ARMH's TTC time: it at once explains why it took so long before the second "memorial" transition could be initiated, why it inevitably had to happen now, and why it can be expected to come to a closure in the near future. ${ }^{22}$ As becomes clear from the slogan cited above - "why have the fathers of the transition left my grandfather in the ditch?"- the self-circumscription of ARMH as being a generation of grandchildren does not only refer to a (real or symbolical) kinship relation to a generation of dead grandfathers, it also, by means of a reference to a (real or symbolical) relation with an intermediary generation of fathers, positions ARMH in relation to the democratic transition. Central to this generational representation of recent Spanish history is the idea that the architects of the transition belonged to a generation of fathers who were not yet ready to break through the taboos and silences that came with the secondary trauma they inherited from their own parents. Only with the coming of the third generation, that of grandchildren, these taboos and silences could finally be broken.

Yet, the generational approach also highlights the urgency of the exhumations and the memorial transition as well as their closure in the near future. The generation of grandchildren is not only the first generation able to transcend intergenerational trauma and deal with the past: due to the threefold organic unity of the relation between grandparents, children, and grandchildren, it is also the 
last generation that can do this. Indeed, the argument that testimonies of the generation of grandparents have to be collected before its last surviving members die (cf. Villarroya i Font et al., 2006: 125) stresses the urgency of the exhumation campaign. ${ }^{23}$ Ultimately, the biological associations of the generational approach also (unintentially) imply a pending closure of the "memorial" transition: opponents could use this reasoning to create a specific version of the "ya pasó"-argument, saying that once the grandchildren are gone, remembrance of the victims will automatically become less organic and more "normalized" so that discussion on the past can be shut down.

This notion of potential closure constitutes a central difference between ARMH's "generational" time and Foro's "regenerational" time. One can gain deeper insight into ARMH's construction of TTC time by contrasting it with concepts of time as constructed by Foro-and the latter's concepts of time are indeed as much constructed and no more "natural" than the former's. Again Foro's preference for ideological ties seems directly related to their regenerational time. By focusing on the dead as fallen combatants rather than as lost relatives, Foro evades the inherent finitude of the generational approach. Moreover, the seemingly inherent finitude of death and of the practice of ex- and inhumation themselves are countered by a repeated stress on the fact that Foro volunteers are recovering the (continuing/living) spirit (espiritu) of the dead rather than just their (decomposing) bones. What counts for republican dead also counts for "fascist" dead: The exclamation that fascism is "still alive" (cf. Mestre, 2011a), ${ }^{24}$ the reference to the continuing existence of "tardofranquistas" (transliterated "tardy" Francoists) (cf. Mestre, 2011b), and the claim that "the [Francoist] crime continues" (Foro, 2012) are leitmotifs in Foro discourse.

As is generally the case with the notion of history as teacher of life, the status of the republican dead as examples for the future is in its turn premised on the idea of a cyclical temporal structure of history. Much as it is the case with the pre-modern magistra vitae concept, famously analyzed by Reinhart Koselleck (1979), Foro's magistra vitae concept is closely related to the idea that in history things essentially always remain the same. That Foro volunteers can be "dignified inheritors and continuators" of the struggle of the dead is due to the fact that despite the "dark night of forty years" (Foro, 2011) that came over Spain after republican defeat, and despite the apparent change of the transition, times have not fundamentally changed. The following speech directed to the dead illustrates this point:

We have obtained that you are honored as who you were during life: heroes. Yet no heroes to remember with nostalgia and to visit once a year at the beautiful monument that remembers you, but rather as authentic example for times that although they seem better than the ones you lived, remain under the constant threat of the triumph of paltriness that egoism entails. The scenario is different, but the causes continue to be the same. [...] It is history, the same one it has always been, from Sparta until our days. (Pedreño, 2011)

\section{Exhumations as mobile seminars}

Exhumations and reburials, we argue, have become sites of an educational project through which TTC time is spread to the remotest areas of Spain. The exhumations can be interpreted as "mobile seminars" where people get involved in the memory movement's "milieu de mémoire." 25

If one observes the exhumations closely, one can trace pedagogical techniques that disseminate norms about how to deal with the past. ARMH's pedagogy especially stimulates a cathartic experience in which people become conscious of their trauma, and go through a collective therapy of truth telling and closure.

The first step in ARMH's pedagogy is to make people understand they are victims and that Spain suffers traumatic memory. Silva explains that before the exhumations, "victims of 
dictatorship [...] never felt themselves victims" (Hedyuma, 2012). ARMH campaigners are living exempla of this learning process. They stress that they too have gone through a process of "learning" and "becoming conscious" (ARMH volunteers, Chillón).

The second step of the learning process involves the idea that something needs to be done about the traumatic past and that exhumations are the best option. In Chillón, ARMH referred to examples of previous exhumations to present "common" alternatives for the monument at the grave site-for example, collective reburial (Town meeting Chillón). The team was also clear about bad examples of dealing with the past - often involving unfaithful relatives. At the town meeting, ARMH narrated an exemplary story about how "one of the saddest things a daughter ever told [them] was that 'they could throw the body of [her] father in the river." Silva, as well, clearly expresses what he thinks of families who do not reclaim their relative's remains: "No person, no good person, can be capable of leaving a relative thrown in a ditch like a dog" (ARMH, 2012a).

As said, an important aspect of ARMH therapy is "breaking silences." Silva himself sometimes serves as an exemplum of how he had to learn to do this. On various occasions, he explains how he was "educated to shut up," and how he broke through his own silence during the exhumation campaign (Hedyuma, 2012; Emilio Silva, 2010, commemoration first exhumation, Priaranza del Bierzo).

ARMH frequently stresses the public character of its exhumations. Sometimes grave sites almost literally turn into classrooms where ARMH clarifies what information it deducts from the grave. The head archaeologist gives an explanation daily, using the objects found in the grave as teaching equipment. Occasionally, forensic anthropologists re-assemble skeletons in situ for pedagogical purposes, and local teachers even bring their students to the graves. ARMH invites villagers, and especially relatives, to visit exhumations and share memories (Head archaeologist, Puebla de don Rodrigo; Town meeting and head archaeologist, Chillón). A final aspect of ARMH discourse that is being disseminated through this mass grave pedagogy is the emphasis on relatives as privileged representatives, and on humane values rather than politics. As said, during exhumations and reburials, ARMH pays great attention to relatives. ARMH prefers that relatives, rather than political parties, organize reburials, and during reburials it praises them for their courage. But the best exempla of family values and of how to deal with the past are the ARMH members themselves. On various occasions, the ARMH in Chillón stressed they do the exhumations "de corazón" (with their hearts). One could say that ARMH members embody good grandsons: they commit themselves to the cause because they want to help to find "other people's grandfathers" (ARMH volunteer, Almadén).

During the exhumations, a new dynamic "milieu de mémoire" is created in which ARMH unites volunteers, academics, villagers, and different generations of relatives. On the Chillón reburial, for instance, all villagers and relatives were considered to have become part of the "big family that is the ARMH" (ARMH vice-president, Chillón). ARMH is quite successful in including local communities and new volunteers in their social movement. In Chillón, many families embraced this newly formed "milieu de mémoire" instead of their destroyed "lieu de mémoire"- the monument at the mass grave.

\section{Conclusion}

This article focused on the Spanish exhumation campaign. Yet it primarily did so to discuss the implications of an internationally increasingly dominant "pathologizing" discourse of transitional justice which posits that the past in post-conflict societies is traumatic and should be healed by therapeutic remembrance in order to prevent it from returning and to reach closure. 
Because Spain's case, at first sight, seems the ultimate confirmation of transitional justice assumptions and beliefs, a detailed analysis of this case can help us critically examine these assumptions and beliefs. Although Spain's memory movement is complex, two conclusions can be drawn from a study of its practice and discourse: first, that the Spanish situation does not unequivocally prove the naturalness and universality of TTC time. Although we did identify an organization, ARMH, that does share aspects of TTC time, this notion of time is not always supported and is sometimes even contested by local actors and competing exhumation organizations. These contestations relate to the conceptualization of the past in psychopathological terms as traumatic and the idea of a need for therapy and closure. Therefore, our second conclusion is that the Spanish case demonstrates that transitional justice discourse and TTC time are actively (though not always intentionally) promoted and disseminated. Because the ARMH reaches the smallest villages and remotest places with its exhumations and because it successfully secures broad popular participation, the organization succeeds in spreading transitional justice discourse and TTC time far beyond the more confined realms of international policy-making and academia.

Another question we raised is in what sense one can say-with Ewa Domanska - that "history starts from the grave." We claimed that exhumation practices certainly involve a "historical" dimension but that they can give rise to very different sorts of history. This is self-evident when we define history as "historical narrative." As is well known, the silence of the dead enables the living to represent them in very different ways and integrate them into very different narratives. This is clearly illustrated by the different privileged representations of the dead by ARMH and Foro. In this paper however, we especially focused on a different definition of "history", namely history as a conceptualization of historicity or time. And also on this level, we argue, relatively similar practices of exhumation can reinforce different notions of time. More concretely, we contend that ARMH's exhumations predominantly bolster the idea of a necessary temporal sequence of trauma, therapy, and closure, while we linked Foro's campaign with the prevalence of "regenerational" time.

Finally, with this study about the dissemination of transitional justice discourse and about how exhumation teams engage in different politics of time, we want to contribute to another debate in memory studies. John Torpey (2003) famously argues that the worldwide memory boom has supplanted future-oriented ideologies. The growing focus on historical injustices and on painful pasts, according to him, coincides with a demise of more emancipatory political projects. At first sight, this seems to count for contemporary Spain. The recent dissemination of TTC time and transitional justice discourse in Spain has to be understood in the context of a post-Francoist climate of fear of political confrontation and of conservative opposition against the memory movement. Although this explains why the memory movement feels the need to evade politically provocative positions, we fear that the engagement with TTC time in the long run can have negative effects: we discussed the pathologization of some of the victims' experiences and memory practices, the risks of closure and the tendency toward depoliticization.

Yet, we argue that a focus on past and memory does not necessarily imply the demise of more emancipatory political projects, in the same way as the politics of forgetting and the ya-pasó argument favored by conservative Spain equally show that the opposite of an "obsession" with the past, namely a neglect of the past, does not at all guarantee emancipatory or utopian politics. Since we argue that the risk of depolitization does not result from a focus on past and memory an sich, but rather depends on, among other things, the specific notion of time in which this focus is embedded, we are not pessimistic. On the contrary, since the Spanish memory movement is a very heterogeneous and highly dynamic movement we are convinced it will be able to resist the described risks and safeguard its emancipatory and critical potential. 


\section{Acknowledgements}

We would like to express our gratitude to Koen Aerts, Gita Deneckere, Joost Fontein, Jo Labanyi, Chris Lorenz, Jonah Rubin, Sarah Vanagt, and Kenan Van De Mieroop for discussing drafts. We would especially like to thank Francisco Ferrándiz, ARMH and all our informants.

\section{Funding}

This work was supported by "Research Fund-Flanders" and "IUAP Justice and Populations."

\section{Notes}

1. This article is the result of joining the expertise of Berber Bevernage in philosophy of history and transitional justice, with the results from Lore Colaert's multisited fieldwork in Spain in 2010-2012. Colaert conducted participant observation in different actions of the memory movement (debates, commemorations, protests, etc.), in six exhumations of which five (Candeleda, Calzada de Oropesa, Puebla de don Rodrigo, Columbrianos, Chillón) were of the ARMH, and five reburials of which four (Candeleda, Calzada de Oropesa, Chillón, Pol) were of the ARMH. We also used press documents, publications, and social media of the memory movement.

2. Social anthropologist Francisco Ferrándiz (2013: 20) describes how scholars in Spain are called upon by the memory organizations to participate in the public debate, and how consequently "pools of academics" develop around the different organizations.

3. All translations are ours, unless indicated otherwise.

4. Journalist Diana Martínez (2012) citing ARMH psychologist Raúl de la Fuente.

5. Neither ARMH nor "Federación Estatal de Foros por la Memoria" (Foro) are homogeneous groups: local dynamics can differ from national ones. In this article, we mainly discuss the national ARMH and Foro.

6. For an overview, see Gálvez Biesca (2006), Ferrándiz (2007), and Hispania Nova (2006).

7. "Current" exhumation campaign because there were other exhumations before. In 1939, Franco ordered the exhumation and reburial of all nationalist victims (Ferrándiz, 2011), and soon after the transition, there were some local "republican" exhumations in some regions (cf. Espinosa Maestre, 2007; Hernández García, 1984; Herrero Balsa and Hernández García, 1982; Hristova-Dijkstra, 2007).

8. In the work of Crossland (2002), Aerts and Bevernage (2009), Bevernage (2012: 62-64), and Renshaw (2010: 49-51), we find similar resistances to trauma time - and especially its notion of closure or "exorcism" of the haunting past—in Argentina, South Africa, and Belgium.

9. In Chillón, Lore Colaert conducted participant observation and fieldwork before, during and after the exhumation (11 October 2011-13 November 2011, and before and during the reburial (30 April-1 May 2012).

10. We do not use the real name of our informants to protect their identities.

11. We came across various examples: in La Mazorra, during an exhumation in May 2011, informants told us they frequently brought flowers to the grave during dictatorship; the archaeological report on "Fosa de Turanzas" mentions how neighbors and relatives brought flowers to the mass grave for a long time (cf. Menéndez, 2006); Emilio Silva mentions this practice in an interview in Priaranza (ARMH, 2012a); and the widows of La Barranca in La Rioja engaged in public mourning already during dictatorship (cf. Asociación para la Preservación de la Memoria Histórica en La Rioja, 2011).

12. We draw an analytical contrast between ARMH — with whom we did most of our fieldwork — and Foro to disclose different politics of time. On many other levels, there are also important resemblances between both groups, as well as differences within each of them.

13. It needs to be emphasized, however, that the ARMH, in their other activities, such as public homages, as well stresses the need for justice, and the recovering of the dignity and values of republicans.

14. Layla Renshaw (2011: 63, 144-145) points out that ARMH's metaphors of planted seeds to describe bodies in mass graves also constitute a regenerational discourse. This aim of republican regeneration is however kept implicit, internal, or personal (e.g. on blogs of members rather than of the organization itself). 
15. It is important to remark that in this analysis we only consider effects of certain practices and discourses, that are not necessarily intentional.

16. Psychologist Guillermo Fouce who works with the ARMH for instance calls the "situation" of the victims' relatives "pathological". He however adds an important distinction that points to the interesting diversity and dynamics within the ARMH network,that only their situation is pathological, not how they handle it, and stresses that he does not consider them patients, but victims (2010, Roundtable, Universidad Carlos III).

17. As Layla Renshaw (2011: 145) demonstrates, the inevitability of the memory campaign is also suggested by the comparison campaigners sometimes draw between republican dead in mass graves and planted seeds.

18. Some ARMH supporters make the differentiation that they offer a kind of "normal companionship" in what they consider a "sane and rightful" process, rather than "therapy"; and that this closure is of a symbolic nature, rather than making up for the years of suffering (ARMH collaborators José Ignacio Casado and Guillermo Fouce, 2010, roundtable Universidad Carlos III).

19. In Spain, most mass graves until now are not suddenly discovered but pointed out by victims' relatives or witnesses. In all our fieldwork sites, this was the case.

20. This depoliticizing effect is usually not perceived by the ARMH that often refers to itself as politico but not partidista.

21. This is in line with the research of Aguilar et al. (2011) who demonstrated that in Spain,"less aggressive" transitional justice policies such as withdrawing Francoist symbols are more widely supported than "more risky" measures such as trials.

22. As Wulf Kansteiner (2012) notes, explaining phenomena through generations and family relations is generally a persuasive trope, as it appears to be natural, inevitable, and also innocent since it has not been involved in divisive conflicts as the concepts of race, class, and gender.

23. In Chillón (May 2012), Marco González, vice-president of the ARMH, for instance, stated, "We work against the clock," and during a later reburial in a nearby village, Abenojar, the ARMH head archeaologist explained that they had not waited for individual identifications to return the remains, because many of the attending villagers would not live anymore by then (Cabrera, 2014).

24. Also see "El franquismo aún no ha desaparecido en España": J. M. Pedreño cited in: Diario Siglo XXI (24 December 2010).

25. We borrow the term "milieu de mémoire" from Pierre Nora who wrote in 1989 (p.7) that "lieux de mémoire" or sites of memory were replacing the dissapearing "milieux de mémoire" or environments of memory, which coincided with the collapse of memory and ideologies in the age of globalization. We percieve a return of "milieux de mémoire" in Spain, with different memory organizations engaging in politics of memory.

\section{References}

Aerts K and Bevernage B (2009) Haunting pasts: time and historicity as constructed by the Argentine Madres de Plaza de Mayo and radical Flemish nationalists. Social History 34(4): 391-408.

Agencias (2008) Rajoy: "Abrir heridas del pasado no conduce a nada". El País, 2 September. Available at: http://elpais.com/elpais/2008/09/02/actualidad/1220343425_850215.html (accessed 27 June 2012).

Aguilar P (2002) Memory and Amnesia. New York: Berghahn Books.

Aguilar P, Balcells L and Cebolla-Boado H (2011) Determinants of attitudes toward transitional justice: An empirical analysis of the Spanish case. Comparative Political Studies 44(10): 1397-1430.

Alonso G and Muro D (eds) (2010) The Politics and Memory of Democratic Transition. New York: Routledge. Álvarez Meríno SM (2010) El terror de la incomunicación. Available at: http://www.foroporlamemoria. info/2010/10/el-terror-de-la-incomunicacion-la-represion-que-no-acaba/ (accessed 15 March 2012).

ARMH (2012a) Exhumación de "Los trece de Priaranza" octubre año 2000. Available at: http://www.youtube.com/watch? $\mathrm{v}=\mathrm{v} 2 \mathrm{ZV} 2 \mathrm{t} 1 \mathrm{BFeo} \& ;$ feature $=$ plcp and http://www.youtube.com/watch? $\mathrm{v}=\mathrm{CxB} 1 \mathrm{kDkx} 4$ Ww\&; feature $=$ g-all-u\&context $=$ G273da2bFAAAAAAAAGAA (accessed 27 June 2012). 
ARMH (2012b) 12 años abriendo fosas, cerrando heridas. Available at: http://astorgaenigualdad.blogspot.be/ (accessed 12 June 2012).

ARMH (2012c) Porqué los padres de la transición dejaron a mi abuelo en una cuneta? Available at: http:// www.memoriahistorica.org.es/joomla/index.php/web-links (accessed 28 June 2012).

Asociación para la Preservación de la Memoria Histórica en La Rioja (ed.) (2011) Mujeres de Negro. Logroño: Gráficas Ochoa.

Bevernage B (2012) History, Memory and State-Sponsored Violence. New York: Routledge.

Bolaños V (2010) Jueces e historiadores reclaman en Ponferrada que se investiguen los crímenes del franquismo. Available at: http://www.rtve.es/noticias/20101024/jueces-historiadores-reclaman-ponferradase-investiguen-crimenes-del-franquismo/364399.shtml (accessed 28 June 2012).

Boyd CP (2008) The politics of history and memory in democratic Spain. Annals of the American Academy of Political and Social Science 617: 133-148.

Cabrera E (2014) Siete nombres, cuatro cuerpos. El Diario, 5 May. Available at: http://www.eldiario.es/ sociedad/nombres-cuerpos_0_256524613.html (accessed 20 May 2014).

Crossland Z (2002) Violent spaces: conflict over the reappearance of Argentina's disappeared. In: Schofield J, Johnson WG and Beck CM (eds) Matériel Culture: The archaeology of Twentieth-Century Conflict. London and New York: Routledge, pp. 115-131.

Davis M (2005) Is Spain recovering its memory? Human Rights Quarterly 27(3): 858-880.

Domanska E (2005) Toward the Archaeontology of the dead body. Rethinking History: The Journal of Theory and Practice 9(4): 389-413.

Espinosa Maestre F (2007) De saturaciones y olvidos. Hispania Nova, p. 7.

Fernández de Mata I (2004) The "logics" of violence and Franco's mass graves: an ethnohistorical approach. International Journal of the Humanities 2(3): 2527-2535.

Fernández de Mata I (2010) The rupture of the world and the conflicts of memory. In: Jerez-Farrán C and Amago S (eds) Unearthing Franco's Legacy. Notre Dame, IN: University of Notre Dame Press, pp. 279-303.

Ferrándiz F (2007) Exhumaciones y políticas de la memoria en la España contemporánea. Hispania Nova, p. 7.

Ferrándiz F (2011) Autopsia social de un subtierro. Isegoría 45: 525-544.

Ferrándiz F (2013) Rapid response ethnographies in turbulent times. Researching mass grave exhumations in contemporary Spain. Anthropology Today 29(6): 18-22.

Foro (Federación Estatal de Foros por la Memoria) (2006) Los 5 de Celorio. Available at: http://www.foroporlamemoria.info/2010/11/“los-cinco-de-celorio"/ (accessed 27 March 2012).

Foro (Federación Estatal de Foros por la Memoria) (2010) Arqueología contra la impunidad. Rebelión, 20 April.

Foro (Federación Estatal de Foros por la Memoria) (2011) Menasalbas (Toledo), 16 Julio de 2011. Available at: http://www.foroporlamemoria.info/2011/07/menasalbas-toledo-16-de-julio-de-2011/ (accessed 20 March 2012).

Foro (Federación Estatal de Foros por la Memoria) (2012) Respuestas de la Federación de Foros al cuestionario del Ararteko. Available at: http://www.foroporlamemoria.info/2012/02/respuestas-de-la-federacion-de-foros-al-cuestionario-del-ararteko-defensoria-del-pueblo-de-la-c-autonoma-vasca/ (accessed 15 March 2012).

Foro por la Memoria de Córdoba (2004) Crónicas del silencio [Documentary on excavation by the Foro in Santaella, Córdoba]. Available at: http://www.foromemoriacordoba.org/?p=21 (accessed 12 March 2012).

Gálvez Biesca S (2006) El proceso de la recuperación de la "memoria histórica” en España: Una aproximación a los movimientos sociales por la memoria. International Journal of Iberian Studies 19(1): 25-51.

García Bilbao PA (2010) A la Brigada de la Fosa de Mensalbas. Available at: http://www.foroporlamemoria. info/2010/07/a-la-brigada-de-la-fosa-de-menasalbas/ (accessed 20 March 2012).

Hedyuma (2012) Emilio Silva. juicio a Garzón. 7.2.2012. Available at: http://www.youtube.com/ watch? $\mathrm{v}=$ ONPAu40LLx4 (accessed 28 June 2012).

Hernández García A (1984) La represión en la Rioja durante la Guerra Civil. Logroño: Almazán. 
Herrero Balsa G and Hernández García A (1982) La represión en Soria durante la Guerra Civil. Soria: Almazán.

Hispania Nova (2006) Dossier "Generaciones y memoria de la represión franquista: Un balance de los movimientos por la memoria" (Number 6). Available at: http://hispanianova.rediris.es/6/dossier.htm

Hristova-Dijkstra M (2007) Memoria, olvido y la apertura de las fosas comunes de la guerra civil en 19781981 y 2000-2006. Master's Thesis, University of Groningen, Groningen.

Kansteiner W (2012) Moral pitfalls of memory studies. Memory Studies 5(2): 111-113.

Koselleck R (1979) Historia Magistra Vitae. In: Koselleck R (ed.) Vergangene Zukunft: Zur Semantik geschichtlicher Zeiten. Frankfurt am Main: Suhrkamp, pp. 38-66.

LaManchaRojaTV (2010) Jose Maria Pedreño en el Homenaje a las víctimas del franquismo de Menasalbas. Available at: http://partidocomunistaclm.wordpress.com/2010/07/28/jose-maria-pedreno-en-el-homenaje-a-las-victimas-del-franquismo-de-menasalbas/ (accessed 20 May 2013).

Las fosas del silencio (2003) Armengou M and Belis R. [Film] Spain:30 Minuts/Televisió de Catalunya.

Macías S (2003) Las fosas de la memoria. In: Silva E and Macías S (eds) Las fosas de Franco. Madrid: Ediciones Temas de Hoy, pp. 127-338.

Mansilla Escudero J and Montes Oviedo LM (2009) El crimen de El Contadero. Chillón: Lozano Artes Gráficos.

Martínez D (2012) En las fosas no hay política, hay humanidad. La Crónica, 23 March, p. 18.

Menéndez A (2006) Informe Arqueológico de las excavaciones realizadas en la fosa de Turanzas (Posada de Llanes, Asturias). Available at: http://www.foroporlamemoria.info/noticia.php?id_noticia=782 (accessed 29 May 2014).

Mestre J (2010) Una exhumación frustrada o la transición española como neurosis obsesiva. Rebelión, 29 March. Available at: http://www.rebelion.org/noticia.php?id=103173 (accessed 29 May 2014).

Mestre J (2011a) ¡Nos dejan los cuerpos donde estaban, un respeto a las víctimas del fascismo!Rebelion, 6 August. Available at: http://tenacarlos.wordpress.com/2011/08/06/una-cita-en-poyales-del-hoyo-avilamanana-domingo-en-homenaje-a-las-victimas-del-terror-franquista-y-del-alcalde-del-pp-antonio-cerro/ (accessed 29 May 2014).

Mestre J (2011b) Sobre el potencial práctico de la ley de memoria histórica española como ley de punto final. Rebelion, 6 January. Available at: http://www.rebelion.org/noticia.php?id=119842 (accessed 29 May 2014).

Nora P (1989) Between Memory and History: Les Lieux de Mémoire. Representations (26): 7-24.

Osborne P (1995) The Politics of Time. New York: Verso.

Pedreño JM (2011) Carta a los camaradas asesinados en Menasalbas (16 July 2011). Available at: http://www. foroporlamemoria.info/2011/07/carta-a-los-camaradas-asesinados-en-menasalbas/ (accessed 14 March 2012).

Pérez C, Portalo F, Arroyo, et al. (2010) Arqueólogos desplazados a Candeleda puntualizan detalles sobre la cancelación de la exhumación prevista a fusilados en la guerra civil. Rebelión, 16 April. Available at: http://www.rebelion.org/noticia.php?id=104137 (accessed 29 May 2014)

Renshaw L (2010) Missing bodies near at hand: the dissonant memory and dormant graves of the Spanish Civil War. In: Bille M, Hastrup F and Soerensen TF (eds) An Anthropology of Absence: Materializations of Transcendence and Loss. New York: Springer, pp. 45-62.

Renshaw L (2011) Exhuming Loss: Memory, Materiality, and Mass Graves of the Spanish Civil War. Walnut Creek, CA: Left Coast Press.

Ruiz J (2009) Seventy years on: Historians and Repression during and after the Spanish Civil War. Journal of Contemporary History 44(3): 449-472.

Servimedia (2012) Fosas cerradas, heridas abiertas. Público, 24 January. Available at: http://www.publico. es/418442/fosas-cerradas-heridas-abiertas (accessed 29 March 2012).

Silva E (2000) Mi Abuelo También Fue Un Desaparecido. La Crónica de León, 8 December. Available at: http://www.derechos.net/esp/algomas/silva.html(accessed 29 May 2014)

Silva E (2007) Las fosas del franquismo, desenterrar la memoria. In: Cuadernos del Caum, Charla del Ciclo sobre Memoria Histórica, May, 2-9. Available at: http://www.caum.es/CARPETAS/cuadernos/cuadernospdf/libro16/Fosas_del_franquismo.pdf (accessed 29 May 2014). 
Silva E (2008) La tierra ya no duerme. In: Bernad C and Alonso E (eds) La memoria de la tierra: Exhumaciones de asesinados por la represión franquista. Madrid: Editorial Tébar, pp.13-15.

Silva E (2010) Algunas preguntas sobre la foto de la Andaya (Email interview 16 August 2010).

Silva E (2011) Niebla negra. In: Ferrándiz F and Martínez C (eds) Desvelados. Pamplona: Alkibla Editorial, pp.11-15.

Silva E and Macías S (2003) Las fosas de Franco. Madrid: Ediciones Temas de Hoy.

Teitel RG (2003) Transitional justice genealogy. Harvard Human Rights Journal 16: 69-94.

Torpey J (2003) Politics and the past: On repairing historical injustices. Lanham: Rowman and Littlefield. Tutu D (1998) Report of the Truth and Reconciliation Commission of South Africa (Volume 1). Cape Town. Villarroya i Font J, Alonso A, Bedera Bravo R, et al. (2006) La represión franquista: mito, olvido y memoria (coordinated by ARMH Valladolid \& ARMH Palencia). Valladolid: Universidad de Valladolid.

\section{Author biographies}

Berber Bevernage is Assistant Professor of philosophy and theory of history at the Department of History at Ghent University. He has published in journals such as History and Theory, Social History and History Workshop Journal. His book History, Memory, and State-Sponsored Violence: Time and Justice was published by Routledge in 2012. Berber is co-initiator of the recently launched "International Network for Theory of History" (INTH) which aims to foster collaboration and the exchange of ideas among theorists of history around the world.

Lore Colaert is research fellow at Ghent University's History Department, member of the "International Network for Theory of History," and co-initiator of the Spanish research network "Memorias en Red." She is working on a PhD on politics of memory in Spain, for which she conducted participant observation in exhumations of mass graves from the Civil War and dictatorship. She has also collaborated on two documentaries on this subject: "The Wave" of S. Vanagt and "La Cuchara" of J. Moreno. 